\title{
REPRESENTASI PENDIDIKAN KARAKTER DALAM DAKWAH ISLAM DI MEDIA SOSIAL
}

\author{
Abdi Wael ${ }^{1}$ Hasanudin Tinggapy ${ }^{2}$ Abdul Rasyid Rumata $^{3}$ A. Yusdianti Tenriawali ${ }^{4}$ \\ Ibnu Hajar ${ }^{5}$ Chairul Basrun Umanailo ${ }^{6}$ \\ ${ }^{1,2,3}$ Fakultas Agama Islam, Universitas Iqra Buru \\ ${ }^{4}$ Fakultas Sastra, Universitas Iqra Buru \\ ${ }^{5}$ Fakultas Keguruan dan Ilmu Pendidikan, Universitas Iqra Buru \\ ${ }^{6}$ Fakultas Pertanian dan Kehutanan, Universitas Iqra Buru \\ 1,2,3,4,5,6 Jl. Prof Bassalamah No 1, Namlea, 97571 \\ ${ }^{1}$ Email: abdiwaeluniqbu@gmail.com \\ ${ }^{2}$ Email: _hasanudintinggapyuniqbu@gmail.com \\ ${ }^{3}$ Email: rasyidrumatauniqbu@gmail.com \\ ${ }^{4}$ Email: tenriawali@gmail.com \\ ${ }^{5}$ Email: ibnuhjr423@gmail.com \\ ${ }^{6}$ Email: chairulbasrun@gmail.com
}

\begin{abstract}
ABSTRAK
Penelitian ini bertujuan untuk mengetahui bagaimana representasi nilai penidikan karakter dalam dakwah Islam di media sosial. Penelitian ini merupakan penelitian deskriptif kualitatif. Populasi dalam penelitian ini adalah video dakwah Islam di media sosial Youtube. Teknik pengumpulan data dalam penelitian ini menggunakan teknik dokumentasi dan teknik catat. Data yang telah terkumpul kemudian dianalisis berdasarkan teori representasi untuk mendeskripsikan representasi nilai pendidikan karakter yang terdapat dalam video dakwah islam di media sosial Youtube. Hasil penelitian menunjukkan dakwah Islam di media sosial khususnya Youtube merepresentasikan nilai pendidikan karakter berupa kejujuran, toleransi, disiplin, kerja keras, mandiri, cinta tanah air, bersahabat, dan tanggung jawab. Tema-tema tersebut sesuai dengan unsur-unsur pendidikan karakter yang dirumuskan oleh Kemendiknas tahun 2010. Representasi nilai pendidikan karakter dalam dakwah Islam di media sosial tersebut dapat dimanfaatkan sebagai media pengajaran pendidikan karakter di sekolah.
\end{abstract}

Kata Kunci: Dakwah, Media Sosial, Pendidikan Karakter

\begin{abstract}
This study aims to determine how the representation of the value of character education in Islamic preaching on social media. This research is a qualitative descriptive study. The population in this study were videos of Islamic da'wah on YouTube social media. Data collection techniques in this study used documentation techniques and note-taking techniques. The data that has been collected is then analyzed based on representation theory to describe the representation of the value of character education contained in Islamic da'wah videos on Youtube social media. The results showed that the preaching of Islam on social media, especially Youtube, represented the value of character education in the form of honesty, tolerance, discipline, hard work, independence, love for the country, friendship, and responsibility. These themes are in accordance with the elements of character education formulated by Kemendiknas in 2010. The representation of the value of character education in Islamic preaching on social media can be used as a medium for teaching character education in schools.
\end{abstract}

Keyword: Da'wah, Social Media, Character Building 


\section{PENDAHULUAN}

Manusia mempunyai kewajiban mengingatkan menuju kebaikan, mengingat dan menggerakkan kebaikan. Hubungan diantara manusia akan mempengaruhi sikap dan perilaku mereka, maka umat islam haruslah menyeru serta mengajak pada kebaikan. Hal itu dikenal dengan istilah "Dakwah". Dakwah yang merupakan tugas suci setiap insan juga dijelaskan oleh Prof. Moh. Ali Aziz, bahwa dakwah merupakan kewjiban yang harus dikerjakan dengan penuh kesungguhan oleh setiap umat islam atau segala bentuk aktfitas penyampaian ajaran islam kepada orang lain dengan berbagai cara bijaksana utuk tercapainya individu dan masyarakat yang menghayati dan mengamalkan ajaran islam dalam semua lapangan kehidupan. Dakwah sebagaimana dikatakan oleh Syekh Ali Mahfud adalah mendorong manusia untuk berbuat kebajikan dan mengikuti petunjuk (agama), menyeru mereka kepada kebaikan dan mencegah mereka dari perbuatan mungkar agar mereka memperoleh kebahagiaan didunia dan akhirat (Aziz, 1993).

Saat ini terlihat adanya kecenderungan para pendakwah di media sosial mengangkat tema dakwah yang mengandung nilai pendidikan karakter. Pendidikan karakter adalah usaha manusia secara sadar dan terencana dalam hal mendidik sekaligus memberdayakan peserta didik dengan tujuan membangun karakter pribadi peserta didik. Tentu saja hal ini dilakukan agar nantinya peserta didik menjadi individu yang bermanfaat bagi diri sendiri dan orang banyak. Pendidikan karakter merupakan pendidikan dengan pendekatan langsung pada peserta didik dengan tujuan menanamkan nilai moral sehingga dapat mencegah perilaku yang dilarang. Pendidikan karakter berhubungan erat dengan psikis individu. Dengan pendidikan karakter, dapat diajarkan pandangan tentang nilai-nilai kehidupan, contohnya kejujuran, kepedulian, tanggung jawab, hingga keimanan. Nilai-nilai kehidupan tersebut yang biasa diangkat menjadi tema dakwah di media sosial.

Perwujudan dakwah bukan sekedar usaha peningkatan pemahaman keagamaan dan tingkah laku saja, tetapi juga menuju sasaran yang lebih luas (Syukir, 1983). Pendakwah sebagai salah satu unsur dari dakwah memiliki peran yang penting. Mulai dari mengetahui bagaimana cara berdakwah, mengolah materi yang akan disampaikan dan mengemas aktivitas dakwah se-efektif mungkin agar materi yang disampaikan dipahami, suatu proses dakwah tentunya memiliki strategi. Strategi merupakan rencana atau tindakan (rangkaian kegiatan dakwah) termasuk penggunaan metode dan pemanfaatan sumber daya atau kekuatan yang dimiliki oleh pendakwah. Retorika dakwah termasuk dalam strategi yang digunakan pendakwah. 
Retorika dakwah berasal dari dua kata yaitu retorika dan dakwah. Retorika berarti kesenian untuk berbicara baik yang dicapai berdasarkan bakat alam (talenta) dan keterampilan teknis (Hendrikus, 1991). Sedangkan menurut bahasa, dakwah berarti panggilan, seruan atau ajakan (Saputra, 2012). Jika digabungkan keduanya maka retorika dakwah adalah seni bicara mempengaruhi orang lain melalui pesan dakwah. Retorika dakwah merupakan seni berbicara dalam menyampaikan ajaran Islam secara benar (Abdullah, 2009).

Zaman sekarang banyak sekali para pendakwah yang memodifikasi metode dakwahnya. YouTube adalah media yang efektif untuk digunakan berdakwah karena bukan hanya audio saja yang disajikan, tetapi audio dan visual. Jadi masyarakat dapat mendengarkan dan menyimak dakwahnya sekaligus melihat gambarnya. Pemilihan media yang tepat akan menunjang keberhasilan dakwah bagi setiap para da'i. Oleh karena itu, apakah dakwah Islam di media sosial merepresentasikan nilai pendidikan karakter menjadi fokus permasalahan dalam penelitian ini. Penelitian ini bertujuan untuk mengetahui representasi pendidikan karakter dalam dakwah Islam di media sosial. Adapun penelitian sebelumnya tentang pendidikan karakter dalam dakwah pernah dilakukan oleh Musrifah dengan judul penelitian 'Pendidikan Karakter dalam Perspektif Islam'. Hasil penelitian menunjukkan bahwa tujuan utama pendidikan karakter menurut islam adalah membentuk kepribadian peserta didik sehingga memiliki etika, dan rasa berbudaya yang baik serta mewujudkannya dalam kehidupan sehari-hari (Musrifah, 2016). Penelitian relevan selanjutnya pernah dilakukan oleh Langga dengan judul penelitian 'Representasi Islami dalam Animasi Nussa Sebagai Media Pembelajaran Untuk Anak'. Hasil penelitian menunjukkan bahwa penggunaan elemen dan atribut yang didominasi nuansa keislaman saling mendukung satu sama lain sehingga memperkuat citra animasi Nussa sebagai edutainment dengan representasi islami (Langga, 2020). Adapun perbedaan penelitian ini dengan penelitian terdahulu yaitu fokus penelitian ini untuk menemukan representasi nilai pendidikan karakter dalam dakwah Islam di media sosial. Serta adanya peluang pemanfaatan dakwah Islam di media sosial sebagai media pembelajaran pendidikan karakter.

Penelitian ini penting untuk dilakukan mengingat sebagian kalangan masyarakat di Indonesia menganggap beberapa video ceramah yang tersebar di Youtube mengandung konten yang menyerukan kekerasan. Sehingga melalui penelitian ini, diharapkan dapat diketahui bahwa di dalam dakwah di media sosial tidaklah selalu merepresentasikan 
kekerasan melainkan juga terdapat nilai pendidikan karakter di dalam video dakwah yang beredar saat ini.

Dalam penelitian ini ada dua kata kunci yang konsepnya harus diperjelas, yaitu representasi, dan pendidikan karakter. Kata representasi (to represent) memiliki tiga makna, yaitu: Pertama, to stand for. Hal ini dapat dicontohkan dalam kasus bendera negara yang jika dikibarkan dalam suatu event olahraga, maka bendera tersebut menandakan keberadaan negara yang diwakili bendera tersebut dalam event olahraga itu. Kedua, to speak or act on behalf of. Dalam hal ini dapat dicontohkan pada saat seorang ketua RT berbicara dan bertindak atas nama warga yang diwakilinya. Ketiga, to re-present. Contohnya pada tulisan sejarah atau biografi yang dapat menghadirkan kembali kejadiankejadian di masa lalu (Giles, Judy \& Middleton, 1999). 'Representasi' sebagai “...an essential part of the process by which meaning is produced and exchanged between members of culture". Representasi merupakan salah satu bagian terpenting dalam proses produksi makna (Hall, 2003). Suatu makna diproduksi dan dipertukarkan antar anggota masyarakat, sehingga representasi merupakan suatu cara untuk memproduksi makna.

Ada dua proses representasi. Pertama, representasi mental, yaitu konsep tentang 'sesuatu' yang ada di kepala kita masing-masing (peta konseptual), representasi mental masih merupakan sesuatu yang abstrak. Kedua, 'bahasa' yang berperan penting dalam proses konstruksi makna. Konsep abstrak yang ada dalam kepala kita harus diterjemahkan dalam 'bahasa' yang lazim, supaya kita dapat menghubungkan konsep dan ide-ide kita tentang sesuatu dengan tanda dari simbol-simbol tertentu. Media sebagai suatu teks banyak menebarkan bentuk-bentuk representasi pada isinya (Hall, 2003).

Istilah representasi dalam konteks pemberitaan merujuk pada bagaimana seseorang, suatu kelompok, gagasan atau pendapat tertentu ditampilkan (Eriyanto, 2003). Hal yang perlu diperhatikan menyangkut hal representasi, yaitu apakah seseorang, kelompok, atau gagasan tersebut ditampilkan sebagaimana mestinya. Apakah seseorang atau kelompok tersebut diberitakan apa adaya, ataukah diburukkan. Bagaimana representasi tersebut ditampilkan. Kata, kalimat, tanda apa saja yang digunakan untuk melakukan representasi tentang sesuatu. Hal tersebut sesuai dengan pendapat Van Leeuwen: 'representations include or exclude social actors to suit their interests and purposes in relation to the readers for whom they are intended'. Setiap pernyataan dalam teks berita merupakan pilihan seorang wartawan berdasarkan tujuan yang diinginkannya (Leeuwen, 2008).

Pendidikan Islam adalah suatu proses pembentukan akhlak atau kepribadian edukatif. Pengertian pendidikan seperti disebutkan di atas mengacu kepada suatu sistem yaitu 
"pendidikan Islam method" atau "Sistem pendidikan Islam" (Ramayulis, 1994). Dalam pengertian secara umum pendidikan dapat diartikan sebagai proses transisi pengetahuan dari satu orang kepada orang lainnya atau dari satu generasi ke generasi lainnya. Semua itu dapat berlangsung seumur hidup, selama manusia masih berada di muka bumi ini.

Dengan demikian karakter juga dapat diartikan sebagai kepribadian atau akhlak. Kepribadian merupakan ciri, karakteristik, atau sifat khas dalam diri seseorang. Karakter bisa terbentuk melalui lingkungan, misalnya lingkungan keluarga pada masa kecil ataupun bawaan dari lahir. Ada yang berpendapat baik dan buruknya karakter manusia memanglah bawaan dari lahir. Jika jiwa bawaannya baik, maka manusia itu akan berkarakter baik. Tetapi pendapat itu bisa saja salah. Jika pendapat itu benar, maka pendidikan karakter tidak ada gunanya, karena tidak akan mungkin merubah karakter orang.

Nilai-nilai yang terkandung dalam pendidikan berkarakter yang dirumuskan oleh Kemendiknas (2010) meliputi delapan belas nilai sebagaimana berikut:

1) Religius, yakni sikap dan perilaku yang patuh dalam melaksanakan ajaran agama yang dianutnya, toleran terhadap pelaksanaan ibadah agama lain, dan hidup rukun dengan pemeluk agama lain.

2) Jujur, yakni perilaku yang didasarkan pada upaya menjadikan dirinya sebagai orang yang selalu dapat dipercaya dalam perkataan, tindakan, dan pekerjaan.

3) Toleransi, yakni sikap dan tindakan yang menghargai perbedaan agama, suku, etnis, pendapat, sikap dan tindakan orang lain yang berbeda dari dirinya.

4) Disiplin, yakni tindakan yang menunjukan perilaku tertib dan patuh pada berbagai ketentuan dan peraturan.

5) Kerja keras, yakni tindakan yang menunjukan perilaku tertib dan patuh pada berbegai ketentuan dan peraturan.

6) Kreatif, yakni berpikir dan melakukan sesuatu untuk menghasilkan cara atau hasil baru dari sesuatu yang telah dimiliki.

7) Mandiri, yakni sikap dan perilaku yang tidak mudah tergantung pada orang lain dalam menyelesaikan tugas-tugas.

8) Demokratis, yakni cara berpikir, bersikap, dan bertindak yang menilai sama hak dan kewajiban dirinya dan orang lain.

9) Rasa ingin tahu, yakni sikap dan tindakan yang selalu berupaya untuk mengetahui lebih mendalam dan meluas dari sesuatu yang dipelajarinya, dilihat, dan di dengar. 
10) Semangat kebangsaan, yakni cara berpikir, bertindak, dan berwawasan yang menempatkan kepentingan bamgsa lain negara di atas kepentingan diri dan kelompoknya.

11) Cinta tanah air, yakni cara berpikir, bertindak, dan berwawasan yang menempatkan kepentingan bangsa dan bernegara di atas kepentingan diri dan kelompoknya.

12) Menghargai prestasi, yakni sikap dan tindakan yang mendorong dirinya untuk menghasilkan sesuatu yang berguna bagi masyarakat, dan mengakui, serta menghormati keberhasilan orang lain.

13) Bersahabat/ komunikatif, yakni sikap dan tindakan yang mendorong dirinya untuk menghasilakn sesuatu yang berguna bagi masyarakat, dan mengakui serta menghormati keberhasilan orang lain.

14) Cinta damai, yakni sikap dan tindakan yang mendorong dirinya untuk menghasilkan sesuatu yang berguna bagi masyarakat, dan mengakui, serta menghormati keberhasilan orang lain.

15) Gemar membaca, yakni kebiasaan menyediakan waktu untuk membaca berbagai bacaan yang memberikan kebajikan bagi dirinya.

16) Peduli lingkungan, yakni sikap dan tindakan yang selalu berupaya mencegah kerusakan pada lingkungan alam di sekitarnya, dan mengembangkan upaya-upaya untuk memperbaiki kerusakan alam yang sudah terjadi.

17) Peduli sosial, yakni sikap dan tindakan yang selalu berupaya mencegah kerusakan pada lingkungan alam di sekitarnya, dan mengembangkan upaya-upaya untk memperbaiki kerusakan alam yang sudah terjadi.

18) Tanggung jawab, yakni sikap dan perilaku seseorang untuk melaksanakan tugas dan kewajibannya, yang seharusnya dia lakukan, terhadap diri sendiri, masyarakat, lingkungan (alam, sosial dan budaya), negara dan Tuhan Yang Maha Esa.

Sebagaimana dijelaskan diatas, bahwa karakter identik dengan akhlak, moral, dan etika. Maka dalam persfektif Islam, karakter atau akhlak mulia merupakan suatu hasil dari proses penerapan syariat (ibadah dan muamalah) yang dilandasi oleh kondisi akidah yang kokoh dan bersandar pada al- Qur'an dan al-Sunah (Hadits).

\section{METODE PENELITIAN}

Penelitian ini adalah penelitian deskriptif kualitatif. Penelitian kualitatif dengan metode deskriptif adalah penelitian yang mengidentifikasi, mengklarifikasi, menganalisis data yang telah diperoleh. Pendeskripsiannya berupa penggambaran bahasa sebagaimana 
adanya (Sudaryanto, 2015). Metode penelitian menurut adalah cara untuk memperoleh pengetahuan mengenai objek tertentu dan, karenanya, harus sesuai dengan kodrat keberadaan objek itu sebagaimana yang dinyatakan oleh teori (Faruk, 2012). Oleh karena itu, metode deskriptif kualitatif yaitu metode yang dilakukan dengan cara mendeskripsikan objek material yang akan diteliti secara kualitatif, kemudian disusul dengan analisis (Tenriawali, 2018).

Sumber data dalam penelitian ini adalah media sosial Youtube, sedangkan jenis data dalam penelitian ini adalah video yang dianggap mengandung nilai pendidikan karakter yang terdapat dalam video dakwah di media sosial Youtube. Metode yang digunakan dalam proses pengumpulan data pada penelitian ini adalah metode simak. Metode simak adalah metode yang digunakan untuk memeroleh data dengan melakukan penyimakan terhadap penggunaan bahasa (Mahsun, 2017). Adapun teknik-teknik pengumpulan data yang digunakan untuk melengkapi metode simak tersebut adalah sebagai berikut.

1. Teknik Dokumentasi

Data lisan dalam video dakwah yang telah diamati dan disimak diunduh dalam format mp4 dan didokumentasikan. Selanjutnya video dakwah dalam format mp4 tersebut ditransliterasikan ulang untuk dianalisis.

\section{Teknik Catat}

Teknik catat merupakan teknik lanjutan yang dilakukan ketika menerapkan metode simak. Teknik catat dilakukan dengan cara mencatat data yang dapat diperoleh. Dalam penelitian ini, data yang telah ditandai dalam video dakwah yang mengandung nilai pendidikan karakter selanjutnya disalin ke dalam kartu data untuk dianalisis.

Teknik analisis data disesuaikan dengan kebutuhan penelitian dan permasalahan penelitian. Analisis data yang dilakukan dalam penelitian adalah sebagai berikut.

\section{Identifikasi Data}

Kata dan kalimat yang terdapat dalam video dakwah diidentifikasi untuk menemukan teks atau kalimat yang mengandung nilai pendidikan karakter. Nilai pendidikan karakter tersebut dapat berupa kata atau kalimat yang terdapat dalam perkataan ataupun judul video dakwah.

\section{Klasifikasi Data}

Data yang berupa kata dan kalimat yang mengandung nilai pendidikan karakter pada video dakwah di Youtube, kemudian diklasifikasikan berdasarkan bentuk nilai-nilai yang terkandung dalam pendidikan berkarakter yang dirumuskan oleh Kemendiknas. 
3. Analisis Data

Data yang telah diklasifikasi, dianalisis berdasarkan teori representasi untuk mendeskripsikan representasi nilai pendidikan karakter yang terdapat dalam video dakwah islam di media sosial Youtube.

4. Penyimpulan Hasil Analisis

Pada tahap ini, data yang telah dianalisis selanjutnya diinterpretasikan dan dijelaskan nilai pendidikan karakter yang terkandung di dalam video dakwah islam di Youtube. Dari hasil interpretasi tersebut pada akhirnya terungkap representasi nilai pendidikan karakter dalam dakwah islam di media sosial.

\section{HASIL DAN PEMBAHASAN}

Berdasarkan hasil penelitian, berikut merupakan video dakwah Islam di media sosial yang dianggap merepresentasikan nilai pendidikan karakter.

\begin{tabular}{|c|c|c|c|}
\hline No. & $\begin{array}{c}\text { Nilai Pendidikan } \\
\text { Karakter }\end{array}$ & Judul Video di Media Sosial & Channel Youtube \\
\hline 1 & Kejujuran & $\begin{array}{ll}\text { - } & \text { Kejujuran membawa ke } \\
\text { syurga (UAS) } \\
\text { - } \quad \text { Indahnya kejujuran } \\
\text { bahayanya kedustaan (Ust. } \\
\text { Muhammad Qosim Muhajir, } \\
\text { Lc.) }\end{array}$ & $\begin{array}{ll}\text { - } & \text { ReligiOne } \\
\text { - } & \text { Yufid TV }\end{array}$ \\
\hline 2 & Toleransi & $\begin{array}{ll}\text { - } & \text { Toleransi antar umat } \\
& \text { beragama (UAS) } \\
\text { - } & \text { Bukti Islam itu agama } \\
& \text { toleransi (UAS) } \\
\text { - } & \text { Toleransi (UAS) }\end{array}$ & $\begin{array}{ll}\text { - } & \text { Hidayah Chanel } \\
\text { - } & \text { Al Mujahiddin } \\
\text { - } & \text { Agama Sempurna }\end{array}$ \\
\hline 3 & Disiplin & $\begin{array}{ll}\text { - } & \text { Tentang disiplin (UAS) } \\
\text { - } & \text { Pentingnya disiplin dalam } \\
& \text { waktu (UAS) }\end{array}$ & $\begin{array}{ll}\text { - } & \text { Rivaldi Rahmat } \\
\text { - } & \text { Parsilaungan }\end{array}$ \\
\hline 4 & Kerja Keras & $\begin{array}{ll}\text { - } & \text { Cara membangkitkan } \\
& \text { semangat kerja (UAS) } \\
\text { - } & \text { Motivasi kerja orang Islam }\end{array}$ & $\begin{array}{l}\text { - Dakwah Islamiyah } \\
\text { - } \quad \text { Dakwah Pendek }\end{array}$ \\
\hline 5 & Mandiri & - $\quad$ Hidup mandiri (UAS) & - $\quad$ Medsos Dakwah \\
\hline
\end{tabular}




\begin{tabular}{|c|c|c|c|}
\hline 6 & Cinta Tanah Air & $\begin{array}{ll}- & \text { Cinta tanah air (UAS) } \\
\text { - } & \text { Memupuk rasa cinta tanah air } \\
& \text { sebagai pemuda (UAS) }\end{array}$ & $\begin{array}{ll} & \text { Ghoorib } \\
\text { - } & \text { Dakwah Pendek }\end{array}$ \\
\hline 7 & Bersahabat & $\begin{array}{ll}\text { - } & \text { Arti sahabat dalam Islam } \\
& \text { (UAS) } \\
\text { - } & \text { Sahabat sejati (UAS) }\end{array}$ & $\begin{array}{ll}- & \text { ReligiOne } \\
\text { - } & \text { Dendy Julianata }\end{array}$ \\
\hline 8 & Tanggung Jawab & $\begin{array}{ll}- & \text { Tanggung jawab (UAS) } \\
- & \text { Laki-laki yang baik dan } \\
& \text { bertanggung jawab (UAS) }\end{array}$ & $\begin{array}{ll}\text { - } & \text { Suaramuslim TV } \\
\text { - } & \text { Jamaah UAS }\end{array}$ \\
\hline
\end{tabular}

\section{PEMBAHASAN}

Dakwah Islam di media sosial merepresentasikan nilai pendidikan karakter. Hal tersebut berdasarkan hasil temuan berikut.

1. Kejujuran

Kejujuran adalah sifat atau keadaan jujur yang menunjukkan ketulusan hati dan kejujuran hati. Dalam pendidikan karakter kejujuran berarti perilaku yang didasarkan pada upaya menjadikan dirinya sebagai orang yang selalu dapat dipercaya dalam perkataan, tindakan, dan pekerjaan. Dalam dakwah islam di media sosial Youtube, yang merepresentasikan nilai kejujuran terdapat dalam dakwah yang berjudul "Kejujuran Membawa Ke Surga" oleh Ust. Abdul Somad di channel ReligiOne. Video dakwah yang telah 13 ribu kali ditonton tersebut memberikan himbauan kepada para umat muslim untuk berlaku jujur karena sikap jujur akan mendapatkan ganjaran surga.

Video dakwah islam kedua yang merepresentasikan nilai kejujuran terdapat dalam video yang berjudul "Indahnya Kejujuran Bahayanya Kedustaan” oleh Ust. Muhammad Qosim Muhajir, Lc. di channel Yuvid TV. Video tersebut telah ditonton 56 ribu kali. Secara umum video tersebut mengajarkan kepada umat muslim tentang nilai-nilai kejujuran dan dampak buruk akibat berdusta atau berbohong. Oleh karena itu, dari kedua video dakwah islam di media sosial tersebut di atas secara langsung menunjukkan adanya kecenderungan pengajaran nilai-nilai pendidikan karakter khususnya tentang kejujuran. 

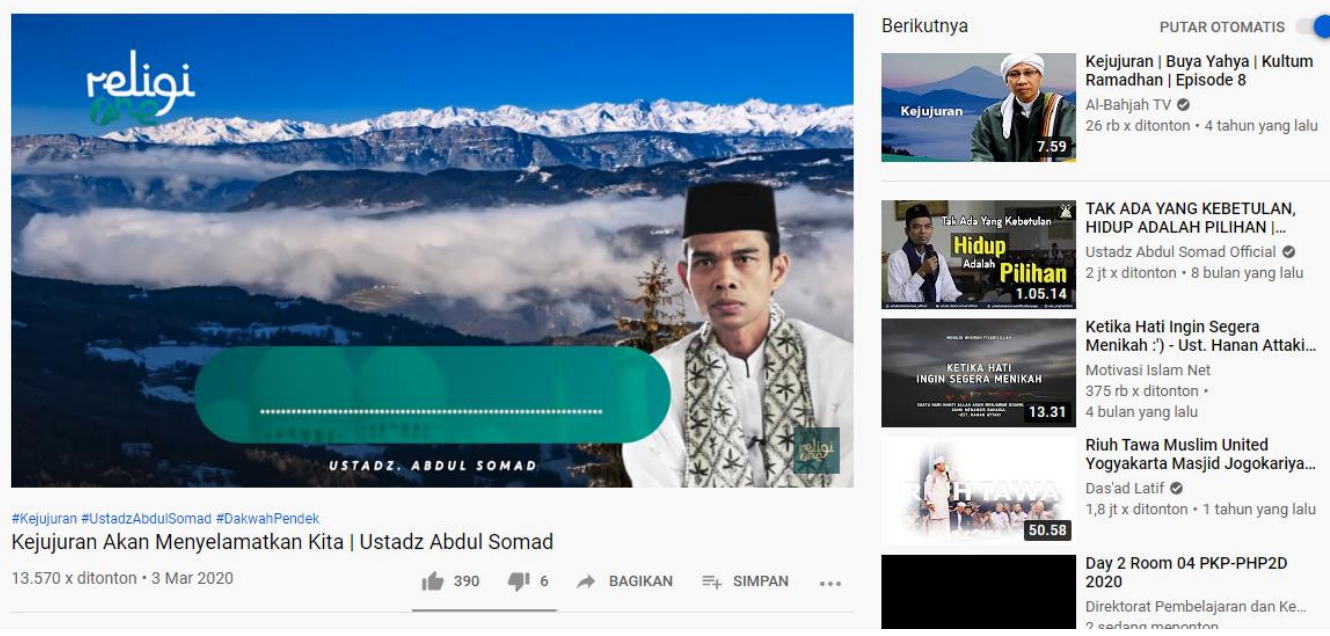

Gambar 1. SC Salah satu video dakwah islam dengan tema kejujuran

2. Toleransi

Toleransi berarti sifat atau sikap toleran. Dalam pendidikan karakter toleransi berarti sikap dan tindakan yang menghargai perbedaan agama, suku, etnis, pendapat, sikap dan tindakan orang lain yang berbeda dari dirinya. Di dalam platform Youtube dakwah islam yang merepresentasikan nilai toleransi adalah dakwah dari Ust. Abdul Somad yang berjudul "Toleransi Antar Umat Beragama" di channel Hidayah Chanel dan "Toleransi" di channel Agama Sempurna yang telah ditonton 1900 kali. Kedua video dakwah islam tersebut membahas tentang apa itu toleransi, dan bagaimana batas-batas toleransi antar umat beragama. Kedua video dakwah islam tersebut secara tidak langsung mengajarkan kepada masyarakat khususnya umat islam tentang bagaimana bersikap toleransi kepada sesama manusia dan antar umat beragama, sehingga video dakwah islam tersebut di atas secara tidak langsung mengajarkan nilai pendidikan karakter kepada masyarakat khususnya yang menonton video ceramah Ust. Abdul Somad tersebut.
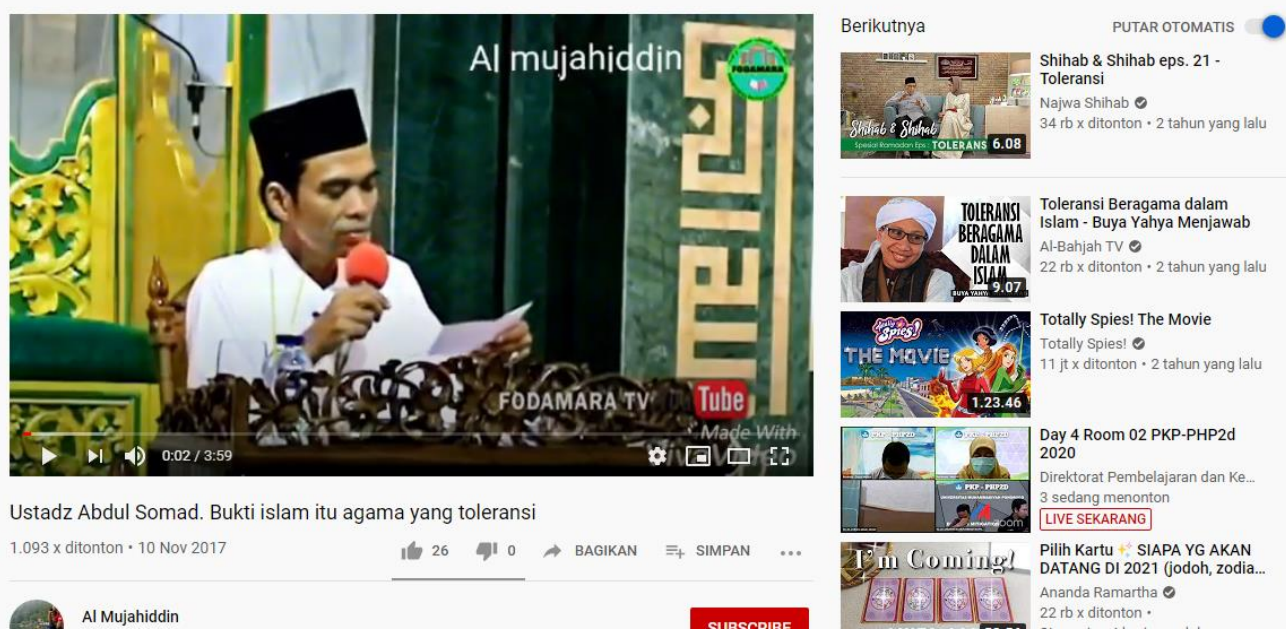

Gambar 2. SC Salah satu video dakwah islam dengan tema toleransi 


\section{Disiplin}

Disiplin merupakan sikap ketaatan atau kepatuhan kepatuhan terhadap tata tertib dan sebagainya. Dalam pendidikan karakter disiplin berarti tindakan yang menunjukan perilaku tertib dan patuh pada berbagai ketentuan dan peraturan. Di media sosial Youtube dakwah Islam yang merepresetasikan nilai kedisiplinan terdapat dalam dakwah Ust. Abdul Somad yang berjudul "Tentang Disiplin" di channel Rivaldi Rahmat yang telah ditonton 5500 kali, serta video yang berjudul "Pentingnya disiplin dalam Waktu" di channel Parsilaungan. Pada dakwah yang berjudul "Tentang Disiplin" Ust. Abdul Somad menghimbau kepada umat muslim untuk selalu berdisiplin dalam segala hal, mulai disiplin dalam pekerjaan, disiplin dalam bekerja, serta berdisiplin dalam segala aktivitas seharihari. Pada dakwah yang berjudul "Pentingnya Disiplin dalam Waktu" Ust. Abdul Somad menghimbau para jemaahnya untuk disiplin dalam memanfaatkan waktu karena waktu tidak dapat kembali lagi sehingga harus dimanfaatkan dengan efisien. Dari kedua dakwah Islam tersebut terlihat bahwa terdapat representasi nilai kedisiplinan dalam dakwah tersebut.
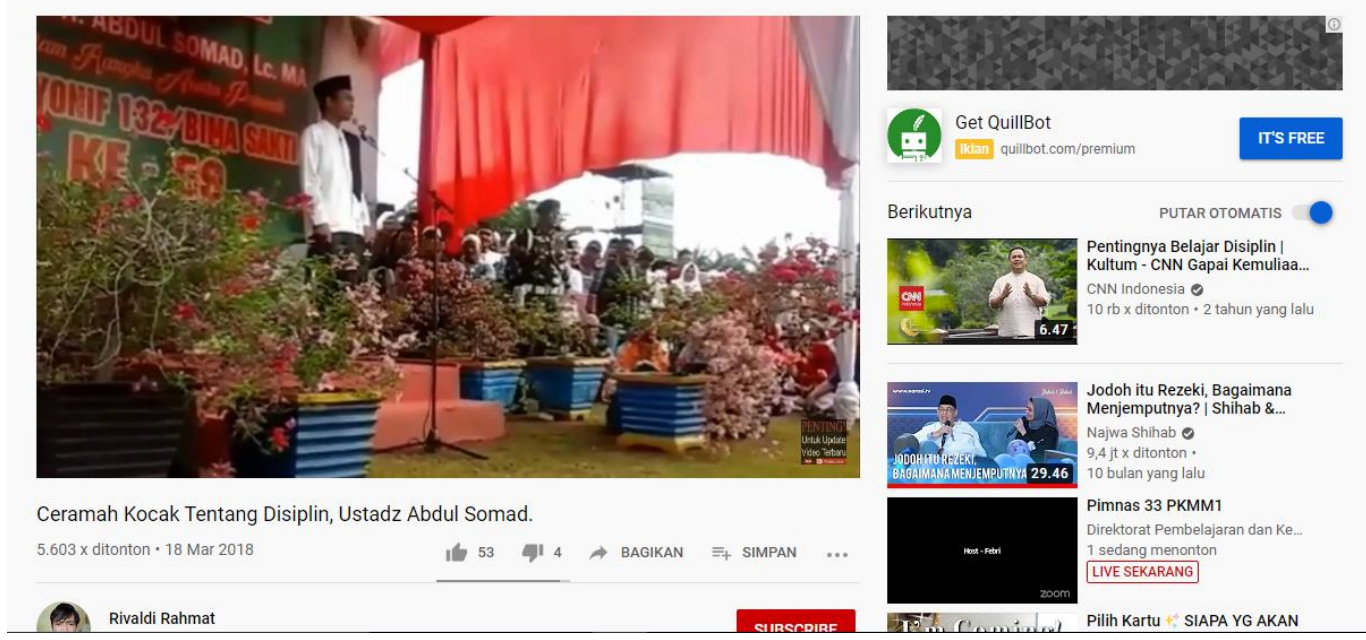

\section{Gambar 3. SC Salah satu video dakwah islam dengan tema disiplin}

\section{Kerja Keras}

Kerja keras berarti kegiatan yang dikerjakan secara sungguh-sungguh tanpa mengenal lelah atau berhenti. Dalam pendidikan karakter kerja keras berarti sikap bersungguh-sungguh dalam mengerjakan sesuatu. Di media sosial Youtube tema sifat kerja keras terdadapat dalam dakwah Islam yang berjudul "Cara Membangkitkan Semangat Kerja" oleh Ust. Abdul Somad di channel Dakwah Islamiyah, yang telah ditonton 471 ribu kali. Serta video dakwah yang berjudul "Motivasi Kerja Orang Islam" di channel Dakwah Pendek yang telah ditonton 146 ribu kali. Kedua dakwah islam yang berjudul "Cara 
membangkitkan Semangat Kerja" dan "Motivasi Kerja Orang Islam" membahas tentang semangat kerja keras dalam islam, bagaimana cara membangkitkan semangat kerja, serta cara membentuk kebiasaan kerja keras dalam diri. Oleh karena itu, dakwah Islam di channel Dakwah Islamiyah dan Dakwah Pendek tersebut merepresentasikan nilai-nilai kerja keras.

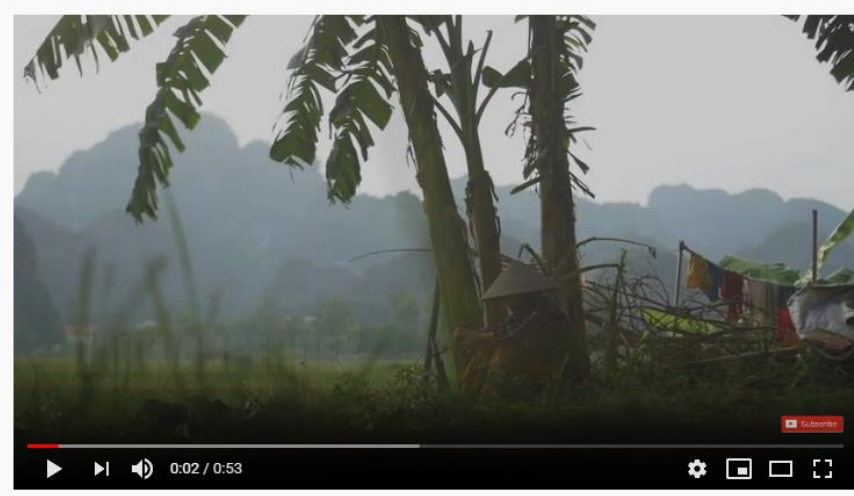

\#ustadzabdulsomad \#ustadzsomad \#ceramah

Motivasi Kerja Orang Islam - Ceramah Pendek Ustadz Abdul Somad Lc.,MA 1 Menit $148.402 \times$ ditonton $\cdot 12$ Apr 2019

It $1,6 \mathrm{RB}$ \& $16 \rightarrow$ BAGIKAN $\equiv+$ SIMPAN

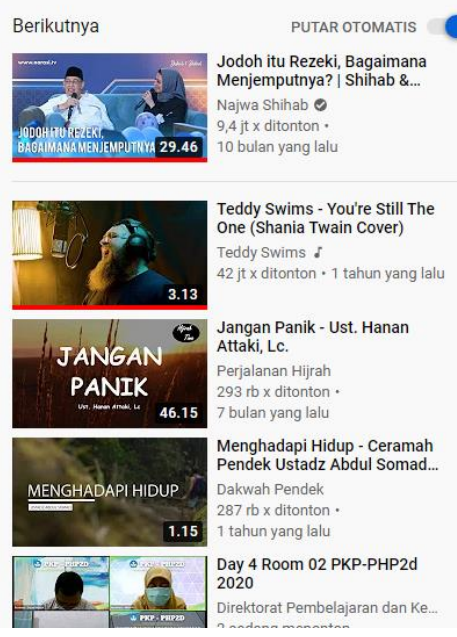

Gambar 4. SC Salah satu video dakwah islam dengan tema kerja keras

5. Mandiri

Mandiri adalah keadaan seseorang yang tidak bergantung pada orang lain. Pada pendidikan karakter, mandiri berarti sikap dan perilaku yang tidak mudah tergantung pada orang lain dalam menyelesaikan tugas-tugas. Di media sosial Youtube dakeah Islam yang membahas tentan kemandirian terdapat dalam dakwah yang berjudul "Hidup Mandiri" oleh Ust. Abdul Somad di channel Medsos Dakwah. Dakwah tersebut membahas tentang bagaimana seharusnya umat islam harus dapat hidup mandiri dan tidak terlalu mudah tergantung pada orang lain. Di dalam dakwah tersebut juga dijelaskan jika Allah Swt. menyukai hambanya yang memiliki sifat mandiri. Oleh karena itu, dakwah islam tersebut merepresentasikan nilai pendidikan karakter berupa kemandirian.

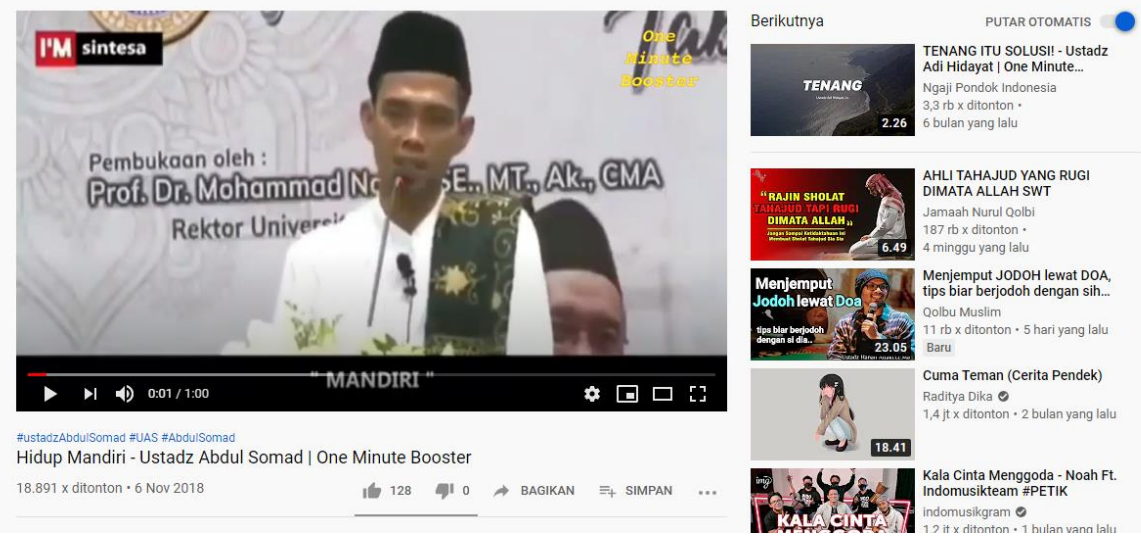

Gambar 5. SC Salah satu video dakwah islam dengan tema mandiri 


\section{Cinta Tanah Air}

Dalam pendidikan karakter, cinta tanah air berarti cara berpikir, bertindak, dan berwawasan yang menempatkan kepentingan bangsa dan bernegara di atas kepentingan diri dan kelompoknya. Di media sosial Youtube, video dakwah yang merepresentasikan nilai cinta tanah air terdapat dalam dakwah Islam yang berjudul "Cinta Tanah Air" oleh Ust. Abdul Somad di channel Ghoorib yang telah ditonton 2200 kali. Serta dakwah yang berjudul "Memupuk Rasa Cinta Tanah Air sebagai Pemuda Muslim" di channel Medsos Dakwah. Kedua video dakwah tersebut membahas tentang apa itu cinta tanah air dalam Islam, serta bagaimana menumbuhkan rasa cinta tanah air dalam diri khususnya menumbuhkan rasa cinta tanah air di kalangan pemuda. Kedua video dakwah tersebut di atas menunjukkan bahwa dakwah Islam juga telah mengangkat tema-tema pembahasan yang mendukung pendidikan karakter.
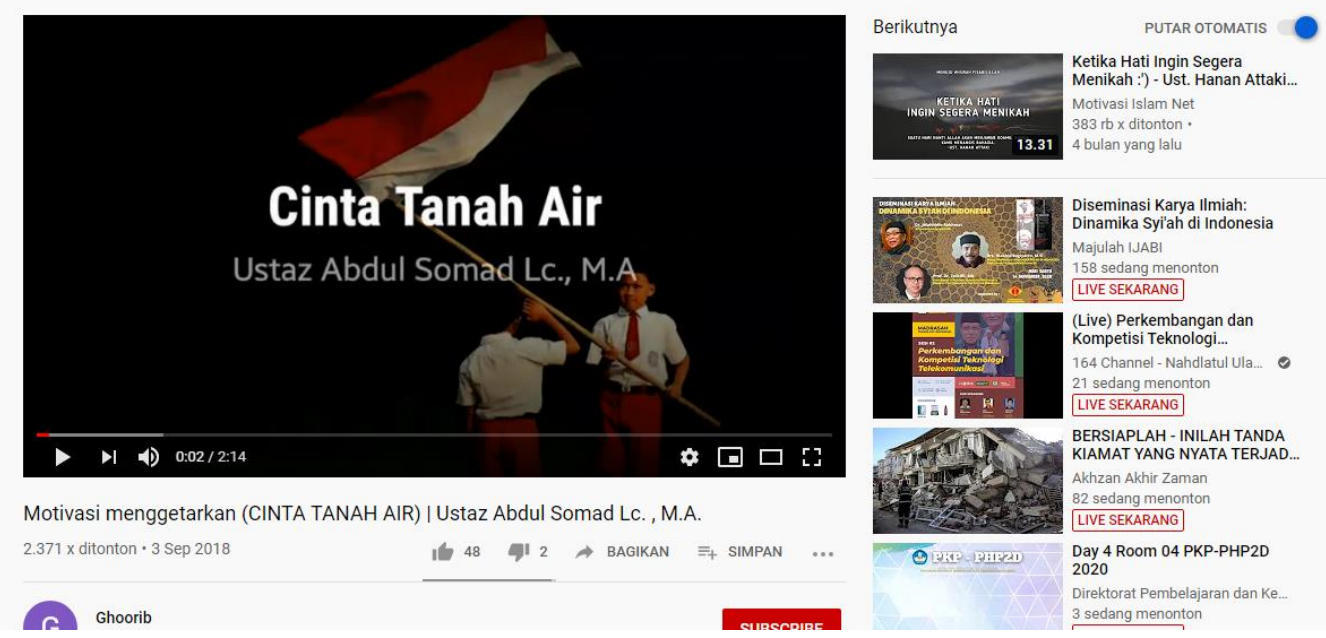

\section{Gambar 6. SC Salah satu video dakwah islam dengan tema cinta tanah air}

\section{Bersahabat}

Dalam pendidikan karakter, bersahabat berarti sikap dan tindakan yang mendorong dirinya untuk menghasilkan sesuatu yang berguna bagi masyarakat, dan mengakui serta menghormati keberhasilan orang lain. Di media sosial Yuotube, dakwah yang membahas tentang sikap bersahabat terdapat dalam dakwah yang berjudul "Arti Sahabat dalam Islam" oleh Ust. Abdul Somad di channel ReligiOne yang telah ditonton 47 ribu kali. Serta video yang berjudul "Sahabat Sejati" di channel Dendy Julianata yang telah ditonton 10 ribu kali. Video dakwah "Arti Sahabat dalam Islam" dan "Sahabat Sejati” membahas tentang apa arti persahabatan dalam Islam, bagaimana cara bersahabat dalam Islam, serta tentang sahabat sejati. Kedua video dakwah tersebut secara tidak langsung merepresentasikan nilai pendidikan karakter tentang sikap bersahabat. 


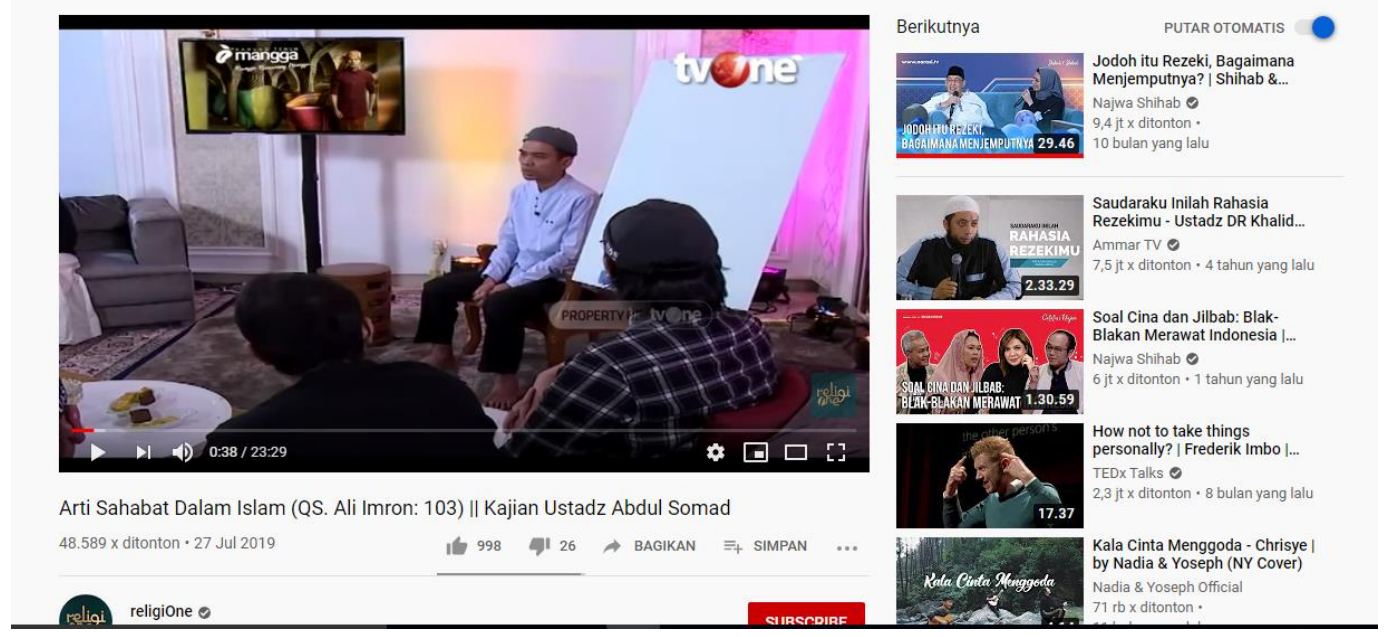

Gambar 7. SC Salah satu video dakwah islam dengan tema bersahabat

8. Tanggung Jawab

Tanggung jawab dalam pendidikan karakter berarti sikap dan perilaku seseorang untuk melaksanakan tugas dan kewajibannya yang seharusnya dia lakukan terhadap diri sendiri, masyarakat, lingkungan (alam, sosial dan budaya), negara dan Tuhan Yang Maha Esa. Di media sosial Youtube nilai tanggung jawab terlihat pada dakwah Islam yang berjudul "Tanggung Jawab" oleh Ust. Abdul Somad di channel Suaramuslim TV dan telah ditonton 3600 kali. Serta dakwah yang berjudul "Laki-laki yang Baik dan Bertanggung Jawab" di channel Jemaah UAS yang telah ditonton 36 ribu kali. Dakwah yang berjudul "Tanggung Jawab" secara umum menjelaskan tentang ruang lingkup tanggung jawab dalam kehidupan sehari-hari bagi umat muslim, sedangkan dakwah yang berjudul "Lakilaki yang Baik dan Bertanggung Jawab" menjelaskan tentang kriteria laki-laki yang baik dan bertanggung jawab dalam Islam. Kedua video dakwah Islam tersebut secara tidak langsung mengajarkan kepada masyarakat khususnya umat muslim tentang sikap tanggung jawab yang termasuk dalam nilai pendidikan karakter.

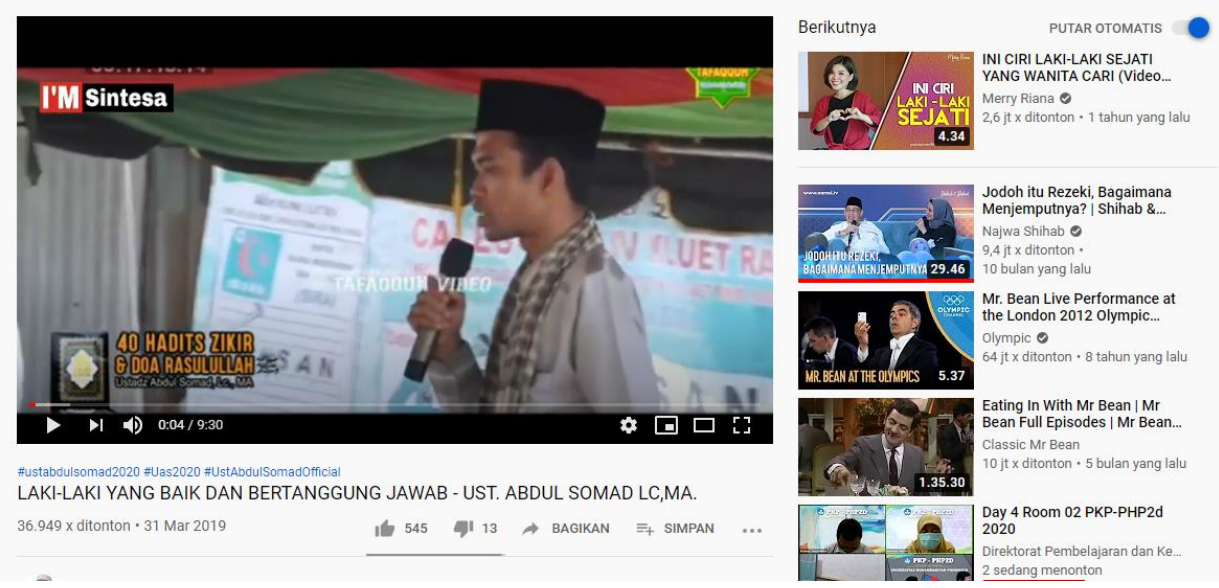

Gambar 8. SC Salah satu video dakwah islam dengan tema tanggung jawab 
Berdasarkan hasil analisis di atas terlihat bahwa dakwah Islam di media sosial khususnya Youtube mengadung konten isi dengan tema kejujuran, toleransi, disiplin, kerja keras, mandiri, cinta tanah air, bersahabat, dan tanggung jawab. Tema-tema tersebut sesuai dengan unsur-unsur pendidikan karakter yang dirumuskan oleh Kemendiknas tahun 2010. Oleh karena itu, dakwah Islam di media sosial memiliki potensi untuk digunakan sebagai bahan ajar pendidikan karakter.

\section{SIMPULAN}

Pendidikan karakter adalah upaya sadar yang dilakukan seseorang atau sekelompok orang (pendidik) untuk menginternalisasikan nilai-nilai karakter pada seseorang yang lain (peserta didik) sebagai pencerahan agar peserta didik mengetahui, berfikir dan bertindak secara bermoral dalam menghadapi setiap situasi. Pendidikan karakter merupakan upaya yang sungguh-sungguh untuk membantu seseorang memahami, peduli dan bertindak dengan landasan nilai-nilai etis. Dari hasil analisis dapat disimpulkan bahwa dakwah Islam di media sosial merepresentasikan nilai pendidikan karakter. Nilai pendidikan karakter yang terdapat dalam video dakwah Islam di media sosial yang ditemukan adalah kejujuran, toleransi, disiplin, kerja keras, mandiri, cinta tanah air, bersahabat, dan tanggung jawab.

Dari hasil penelitian tersebut juga dapat disimpulkan bahwa representasi nilai pendidikan karakter dalam dakwah Islam di media sosial tersebut dapat dimanfaatkan sebagai bahan pengajaran pendidikan karakter di sekolah. Terutama pada pengajaran pendidikan karakter dalam pelajaran pendidikan agama Islam di sekolah.

\section{SARAN}

Berdasarkan hasil penelitian, dakwah Islam di media sosial Youtube mengandung nilai-nilai pendidikan karakter seperti kejujuran, toleransi, disiplin, kerja keras, mandiri, cinta tanah air, bersahabat, dan tanggung jawab. Oleh karena itu, video dakwah Islam di media sosial Youtube dapat digunakan oleh para tenaga pendidik sebagai media pembelajaran untuk pelajaran pendidikan karakter di sekolah.

\section{DAFTAR PUSTAKA}

Abdullah. (2009). Retorika dan Dakwah Islam. Jurnal Dakwah, X(1), 113.

Aziz, M. A. (1993). Diktat Mata Kuliah Dakwah. Fakultas Dakwah IAIN Sunan Ampel. Eriyanto. (2003). Analisis Wacana: Pengantar Analisis Teks Media. LKiS Yogyakarta. Faruk, F. (2012). Metode Penelitian Sastra: Sebuah Penjelajahan Awal. Pustaka Pelajar. 
Giles, Judy \& Middleton, T. (1999). Studying Culture: A Practical Introduction. Blackwell Publisher.

Hall, S. (2003). Representation: Cultural Representation and Signifying Practices. Sage Publication.

Hendrikus, D. W. (1991). Retorika Terampil Berpidato, Berdiskusi, Berargumentasi, Bernegosiasi. Kanisius.

Langga, F. H. (2020). Representasi Islami dalam Animasi "Nussa" Sebagai media Pembelajaran Untuk Anak. Rekam: Jurnal Fotografi, Televisi, Animasi, 16(2), 125.

Leeuwen, T. Van. (2008). Discourse and Practice: New Tools For Critical Discourse Analysis. Oxford University Press.

Mahsun. (2017). Metode Penelitian Bahasa. PT Raja Grafindo Persada.

Musrifah. (2016). Pendidikan Karakter dalam Perspektif Islam. Edukasia Islamika, 1(1), 119.

Saputra, W. (2012). Pengantar Ilmu Dakwah. Rajawali Pers.

Sudaryanto. (2015). Metode dan Aneka Teknik Analisis Bahasa: Pengantar Penelitian Wahana Kebudayaan Secara Linguistik. Duta Wacana University Press.

Syukir, A. (1983). Dasar-dasar Strategi Dakwah Islam. Al-Ikhlas.

Tenriawali, A. Y. (2018). REPRESENTASI KORBAN KEKERASAN DALAM TEKS BERITA DARING TRIBUN TIMUR: ANALISIS WACANA KRITIS (The Representation Victims of Violence in Tribun Timur Online News Text: Critical Discourse Analysis) (Vol. 6). https://doi.org/http://dx.doi.org/10.26499/ttbng.v6i1.71 